\title{
Discussion Paper No. 15-058 \\ Did the Introduction of the Euro Lead to Money Illusion? Empirical Evidence from Germany
}

Benjamin Bittschi and Saskia Duppel

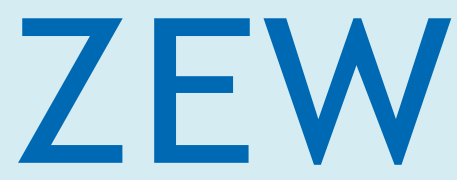

Zentrum für Europäische Wirtschaftsforschung $\mathrm{GmbH}$

Centre for European Economic Research 


\title{
Discussion Paper No. 15-058 \\ Did the Introduction of the Euro Lead to Money Illusion? Empirical Evidence from Germany
}

\author{
Benjamin Bittschi and Saskia Duppel
}

Download this ZEW Discussion Paper from our ftp server:

http://ftp.zew.de/pub/zew-docs/dp/dp15058.pdf

Die Discussion Papers dienen einer möglichst schnellen Verbreitung von neueren Forschungsarbeiten des ZEW. Die Beiträge liegen in alleiniger Verantwortung der Autoren und stellen nicht notwendigerweise die Meinung des ZEW dar.

Discussion Papers are intended to make results of ZEW research promptly available to other economists in order to encourage discussion and suggestions for revisions. The authors are solely responsible for the contents which do not necessarily represent the opinion of the ZEW. 


\title{
Did the introduction of the euro lead to money illusion?

\author{
Empirical evidence from Germany
}

\author{
Benjamin Bittschi* \\ ZEW Mannheim, Karlsruhe Institute of Technology (KIT) \\ Saskia Duppel \\ ZEW Mannheim
}

August 24, 2015

\begin{abstract}
Using the introduction of the euro as a natural experiment, we provide economywide evidence for money illusion based on declared donations from German administrative income tax data. Our results suggest a magnitude of the money illusion effect between $2.4 \%$ and $7.6 \%$. Compared to previous studies on money illusion in the course of the euro currency changeover this effect size is significantly lower. We trace this back to the more comprehensive donation data in our study compared to hitherto studied face-to-face collections, which makes our results less prone to "power of the ask" and social pressure effects.
\end{abstract}

Keywords: Money illusion, euro introduction, charitable giving, natural experiment JEL-Classification: D12, E03, E40

\footnotetext{
*Address: ZEW Centre for European Economic Research, P.O. Box 103443, 68034 Mannheim, Germany. E-Mail: bittschi@zew.de, corresponding author. We would like to thank Friedrich Heinemann, Shafik Hebous and Johannes Voget for helpful comments. We also thank Lukas Grohé and Marlene Helmer for excellent research assistance. For data support we thank Melanie Scheller and Stefanie Uhrich from the Research Data Center of the German Federal Statistical Office. Financial support by the German Research Foundation is gratefully acknowledged.
} 


\section{Introduction}

Neoclassical economic theory assumes that rational agents make their decisions based on relative rather than on nominal values. The nominal price of a good is in terms of money, while the relative or real price of a good is its value in terms of some other good. Since in everyday life prices and wages are usually represented in nominal terms, it demands a high cognitive effort to differentiate between nominal and real prices. In addition, money as a unit of account is not fixed like physical measures such as kilogram or meter, but due to inflation the yardstick of value is changing over time.

Economists and psychologists have suspected for a long time that people in everyday live may not convert goods to real prices but are prone to money illusion, a bias that consists in failing to distinguish between nominal and real transactions. The phenomenon of money illusion is a perennial topic in economics and the question whether it exists or not is vitally important for economic theory as well as for economic policy. Against this background it is astonishing that the literature on money illusion is mainly based on questionnaire studies and laboratory experiments and no attempts exist to gauge the problem on an economy-wide scale.

Therefore, our paper goes beyond the scope of prevalent laboratory settings or smallscaled questionnaires and uses comprehensive German administrative income tax data to investigate economy-wide money illusion. The commodity under study are charitable donations, which is in line with previous literature. Furthermore, also in line with previous literature, we provide empirical evidence on money illusion based on a natural experiment, the introduction of euro cash on 1st January 2002 in the European Economic and Monetary Union (EMU). As the euro started to circulate as a means of payment people had to become familiar with the new face values. The currency changeover provides an exceptional opportunity to investigate whether people are able to pierce the veil of money on the economy or whether their behavior is affected by money illusion. However, disentangling the euro introduction from other (macro)economic shocks that took place 
simultaneously is a major challenge that emerges when using administrative data and foregoing the controlled environment of laboratory experiments. We circumvent these difficulties by adjusting the donations data with external information on disaster related charitable giving.

Our findings suggest a money illusion effect leading to an increase of charitable donations between $2.4 \%$ and $7.6 \%$. Compared to previous studies, assessing a money illusion effect in the course of the Euro introduction between $11 \%$ and $13 \%$, this finding is considerably lower. We trace our lower results back to the fact that our donation data is more comprehensive. In particular, using data embracing a whole year implies longer learning and thus, more possibilities to improve the performance in piercing the nominal veil of money. In assessing the economic influence of money illusion such long term measures are an important complement to short term results of laboratory experiments and field experiments investigating money illusion effects only at the beginning of the currency changeover. Additionally, compared to previous evidence resting on face-to-face and door-to-door collections of donations, conversion difficulties might be less severe when donations are made without the social pressure inherent in such human interactions. Our donations data include more deliberate donation decisions, presumably often made more anonymous via bank transfers or standing orders and hence a further decreased effect of money illusion.

\section{Background and literature}

(Neo)Classical economists (e.g. Lucas 1972) took the view that the exchange in the economy takes place in separate markets for goods (real sector) and money (nominal sector). The goods market determines the equilibrium of relative prices and quantities of goods, while the money market determines the equilibrium money prices proportional to the money stock, known as the classical dichotomy (Grandmont 1983). A consequence of that view is that a fully perceived monetary policy has no effect on real output. Thus, it 
is often referred to as money being a veil on the real economy (Lucas 1972), as it hides, but does not affect real economic processes. According to Leontief's (1936) 'homogeneity postulate' there is no money illusion if demand and supply functions are homogeneous of degree zero in all nominal prices, that is, if both supply and demand depend only on relative prices. Hence, the crucial theoretical assumption is that rational agents base their decisions on relative prices rather than on nominal prices. Since in everyday life prices and wages are usually represented in nominal terms, rational economic decisionmaking demands a high cognitive effort from consumers. The question is then whether consumers are able to distinguish between real and nominal price changes to adapt their decision-making accordingly.

Fisher (1928) coined the term money illusion to describe that individuals are subject to a psychological bias that consists in failing to distinguish transactions in terms of nominal or real values. Since money illusion is regarded as irrational and costly for individuals, the existence of this phenomenon is inconsistent with rational choice theory. However, ultimately it remains an empirical question whether individuals are able to distinguish between transactions represented in real and nominal values or whether their behavior is affected by money illusion.

Current research suggests that money illusion has substantial effects in some settings. Evidence is shown by results of surveys as well as laboratory and natural experiments. Shafir et al. (1997) try to measure money illusion with a questionnaire study. Analyzing hypothetical choices made by the respondents, they find that the individuals' preferences and decisions are affected by nominal representation. Amongst others, they study people's attitudes towards salary increases in times of inflation, and effects of framing transactions in nominal or in real terms on the choice between indexed and un-indexed contracts and conclude that money illusion is a widespread phenomenon. Questionnaires can be a very useful method to examine the characteristics of money illusion at the individual level. However, two major drawbacks emerge from this type of evidence. First, the participants lack the incentive to provide meaningful answers and second, it is not possible to examine 
aggregate effects of individual decisions and adjustment processes.

While Shafir et al. (1997) ask hypothetical questions, Fehr and Tyran (2001) are able to actually observe individual behavior after a nominal shock in a laboratory experiment. They demonstrate that participants react slowly to a shock, because they expect others to exhibit money illusion and provide evidence that this strategic behavior may lead to a substantial aggregate effect. Fehr and Tyran (2001) conclude that money illusion should in principle be considered as potential explanation for sticky price adjustment. Laboratory experiments allow for tight control of all relevant variables and researchers can therefore establish a robust causal link between treatment and outcome. However, laboratory settings are artificial by nature and thus the results may give an indication of the real world behavior, but this must not necessarily hold true (Kooreman et al., 2004). Moreover, outcomes of money illusion in laboratory frameworks depend heavily on the experimental design (Petersen and Winn 2014).

In contrast, natural experiments provide the advantage that the environment is not manipulated and that the policy change was not introduced to influence the dependent variable. On the downside, for more credibility one forgoes the complete control over other influencing factors. A highly relevant natural experiment to investigate money illusion is the currency changeover in the EMU that took place when euro cash was introduced in 2002. Using the introduction of the euro in the Netherlands as a quasi-natural experiment, Kooreman et al. (2004) compare the donations of a house-to-house collection before and after the currency changeover. They find that the increase of donations in 2002 is significantly larger than inflation. Since the change in disposable income was negligible during these years, the authors conclude that individuals suffer from money illusion due to the introduction of the euro. However, in Kooreman et al. (2004) the sample size is quite small and the scope geographically limited to three rural villages in the north of the Netherlands. For Cannon and Cipriani (2006) the euro changeover also serves as natural experiment to study whether there was an effect on church collections. They find an exceptional real increase in church collections in Italy and Ireland. 
Our paper also uses the introduction of the euro as a natural experiment to study money illusion and focuses on charitable giving. The conceptual framework is based on the idea that the currency changeover may have caused changes in real prices in some markets while it left unchanged the real price for donations and thus, provides a suitable object to study money illusion. One might ask whether making donations is determined by rational decision-making or if charity is irrational per se. However, various ways have been identified in which charitable behavior can lead to benefits for the donor: economically via tax deductibility (Clotfelter 1985, 2002), socially via signaling one's wealth or status (Becker 1974, Glazer and Konrad 1996) or psychologically via feeling a warm glow from giving (Andreoni 1990, Dunn et al. 2008). In line with a large body of literature, this study is based on the assumption that the activity of donating can in general be modeled as rational decision-making. The key research question analyzed in this paper thus is the following:

If the real price of a donation does not change due to the currency changeover, then if there is no money illusion and given that all other variables remain constant, there will be no significant change in real annual donations. If, however, real donations show an unusual increase (or decrease), there is evidence for the occurrence of money illusion due to the introduction of the euro.

\section{Potential Channels of Money Illusion}

In the EMU the euro currency had already existed as a unit of account since 1999, but it was only at the beginning of 2002 that the euro cash was introduced. The former currencies immediately lost their legal tender status upon the adoption of the euro. Accordingly, consumers had to become familiar with the new currency from this day on. Aside from empirical evidence for the occurrence of money illusion, the question is through which channels behavior can be affected by such a psychological bias.

First, there might be an anchoring effect, as described by Tversky and Kahnemann 
(1974) and with regard to money, individuals may base their decisions on a set of nominal values (Raghubir and Srivastava, 2002). In case of the introduction of the euro in Germany this corresponds to familiar DM-values serving as an anchor for the new euro prices. Since the conversion to the euro leads to lower nominal values the anchoring effect should result in increasing donations. As consumers become acquainted with the new currency, the anchoring effect is expected to diminish over time.

Second, difference assessment might occur, which means that people not just consider prices, but also their income and budget constraints when making economic decisions. Specifically, consumers assess their transactions by evaluating differences between prices and budgets. Experimental evidence shows that if both income and prices increase proportionately and the difference between income and prices becomes larger, spending actually increases (Soman et al., 2002). Since the introduction of the euro in Germany resulted in lower nominal values, consumers perceive the difference between income and prices as smaller and, contrary to the anchoring effect, donations are expected to fall.

Another channel which might affect behavior is the threshold effect, which implies that certain nominal values are more "attractive" than other values resulting in a "1Euro" effect (Cannon and Cipriani, 2006). For instance, if in Germany a DM 1 threshold price is replaced by 1 euro this would result almost in a doubling of the threshold. With regard to donations, if Germans continue to give attractive amounts, charitable giving will be expected to increase.

Closely related to the threshold effect is finally a potential rounding effect. Since the euro replaced the DM at an exchange rate of $€ 1=$ DM 1,95583, Germans are likely to perform conversion as if $€ 1$ was equal to DM 2. This near-rational behavior is sensible, since the individual losses are quite small (Akerlof and Yellen 1985). This response would lead to an overall decrease in donations, although the aggregate effect is expected to be rather small, because the actual exchange rate is close to the rounding value. 


\section{Data and descriptive statistics}

\subsection{Data}

Our empirical analyses are based on annual income tax data from the German TaxpayerPanel 2001-2008, provided by the German Federal Statistical Office (DESTATIS). The Taxpayer-Panel contains information about approximately 16.4 million tax unit:11 of which we use a $5 \%$ stratified sample drawn by DESTATIS for scientific purposes. As the focus of our study lies on the years surrounding the currency changeover in 2002, we drop the years 2004-2008. For each tax unit the panel comprises more than 1000 tax relevant characteristics (Gerber and Hammer, 2013). The Taxpayer-Panel is designed as a balanced panel and thus only contains consecutively filed tax units over the full observation period. Hence, high-income tax payers are overrepresented, since they are more likely to file their income tax in all years. Concerning charitable giving this is an advantage as the data comprises a sufficiently large number of high-income households which also represent the majority of donations made (Clotfelter, 2002).

With regard to the research question we are particularly interested in the following variables: Claimed donations which equal the total sum of contributions declared by the taxpayer in a certain year. This variable includes donations to charities, to scientific organizations and to foundations. We exclude contributions to political parties and for the establishment of new foundations as they are subject to different tax treatment.

Moreover, for each tax unit we have information on income and tax rate. Additionally, there is some information on socio-demographic characteristics such as the place of residence at the federal state level, age, religion, marital status and the number and age of children. To control for influencing factors on a macro level we complement the tax data with regional GDP and unemployment rates. Regional GDP figures for all German federal states are provided by DESTATIS and regional unemployment rates are obtained from the Federal Employment Agency (see table 3 and table 4 in the appendix). We

\footnotetext{
${ }^{1} \mathrm{~A}$ tax unit can be an individual person (single filer) or a married couple in case of a joint assessment.
} 
use the yearly index on consumer prices from DESTATIS to calculate inflation-adjusted donations and income.

An advantage of using tax data is that reported donations are likely to accurately reflect actual donations, as taxpayers have to attach a receipt to their tax file, which is certified by the charity, in order to prove that the amount declared coincides with the amount reported by the charitable organization. However, since many people such as retired persons do not necessarily have to file an income tax return, the aggregated amount of claimed donations in the Taxpayer-Panel represents a lower bound of total donations in Germany.

\subsection{Descriptive statistics}

Figure 1a presents the yearly sum of donations. It demonstrates a sharp increase in claimed donations of approximately $18 \%$ from $€ 581$ million in the year 2001 to $€ 686$ million in 2002. The increase in 2002 was followed by a slight decrease in 2003 and another increase in 2004. The increasing sum of donations can be decomposed into an increasing number of donors and a rising average donation. However, as depicted in Figure $1 \mathrm{~b}$ the increase of donations is not driven by the extensive margin as the percentage of donors remained relatively stable from 2001 till 2003. Because of some data cleaning the absolute number of tax units is not perfectly constant over the course of the four years under consideration. However, as demonstrated in Figure 4 in the appendix the numbers vary only slightly at approximately 810,500 tax units and the percentage of donors relative to all taxpayers remains stable.

In contrast to the percentage of donors, the average donation varies substantially. From 2001 to 2002 the average amount given increased by $13.6 \%$ from $€ 1,380$ to $€ 1,568$. In 2003, the average donation slightly decreased to $€ 1,549$ per donor. In 2004 , there was a further increase in average donations, accompanied by an increase in the percentage of donors to more than $55 \%$. In particular, the sharp rise in the average amount given in 2002 indicates a change in donation behavior which might have been caused by the 
introduction of the euro.

Figure 1: Donation statistics

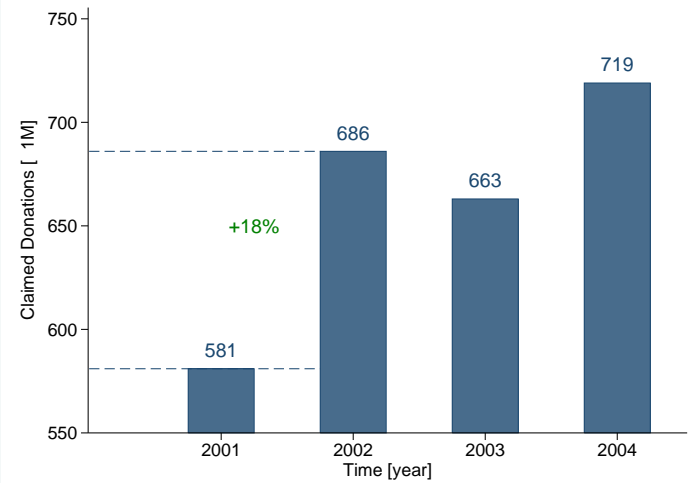

(a) Sum of Claimed Donations

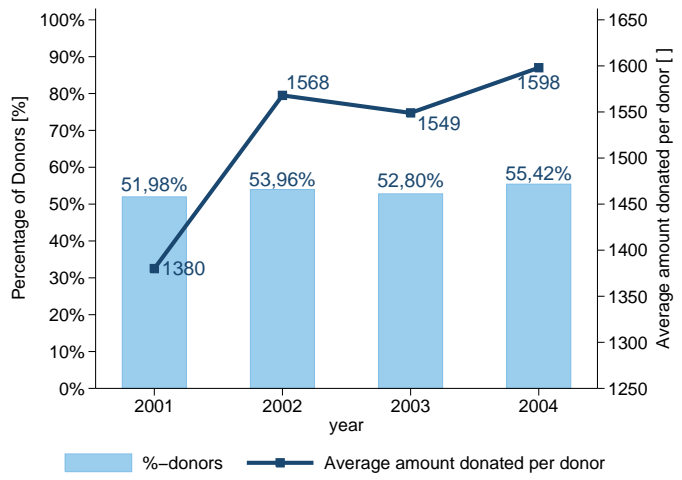

(b) Average Donations and Percentage of Donors

The descriptive statistics can be summarized with two main statements. First, there is strong evidence that donations were significantly higher in the year 2002 compared to 2001. Secondly, it seems that the increase was mainly driven by a rise of the average amount given per donor and less by an increase in the number of donors. This indicates that the change in the giving behavior was caused by a change of individuals' circumstances. The change of individual behavior might be attributed to money illusion due to the introduction of the euro. However, to exclude other influencing factors, such as natural disasters or macroeconomic influences, we scrutinize the introduction of the euro in more detail in the following section.

\section{Empirical strategy}

\subsection{Benchmark model}

Analogous to the specification of demand functions in consumer theory, the literature usually assumes that the demand function for donations is $\mathrm{DON}=\mathrm{f}(\mathrm{I},(1-\tau), \mathrm{X})$, where $\mathrm{I}$ is disposable income, $(1-\tau)$ is the tax price of giving, and $\mathrm{X}$ is a vector of other explanatory 
variables (see for example Andreoni, 2006). Donations can be deducted from gross income and therefore reduce individual tax liability. Due to tax progression, the tax price of giving changes with increasing marginal tax rates and consequently a higher gross income leads to higher tax rates and lower prices of giving. Unobserved heterogeneity plays an important role in estimating charitable donations. Variables such as altruism, wealth or education are generally hard to measure or missing in the data, but they are simultaneously correlated with donations and income. Thus, in the estimation we account for unobserved heterogeneity by adopting tax unit specific fixed effects $\alpha_{i}$ and for common time factors that influence all tax units equally by including time fixed effect $\sigma_{t}$. The main challenge in the estimation will be that, besides the euro introduction, the time fixed effect for 2002 will soak up all other common influences of that year. Thus, after establishing our benchmark model we will present strategies to disentangle the euro effect from other influencing factors.

Applying the two-way FE model described above leads to the following regression equation:

$$
\ln D O N_{i t}=\mu+\beta \ln I_{i t}+\delta \ln \left(1-\tau_{i t}\right)+X_{i t} \gamma+\sigma_{t}+\alpha_{i}+\epsilon_{i t}
$$

As many tax units do not donate we add one euro to the amount of donations in order to be able to logarithmize the dependent variable $2^{2}$ Despite controlling for unobserved heterogeneity some endogeneity problems remain in equation (1). Both, the income and the tax price of giving are direct functions of declared donations and thus endogenous. Hence, we calculate the hypothetical income assuming no declared donations and also a hypothetical marginal tax rate that applies to the first euro donated (Clotfelder 2002). This equals the marginal tax rate at zero donations which is independent of the amount of donations given. This approach is consistent with a large body of literature on charitable

\footnotetext{
${ }^{2}$ The choice of adding $€ 1$ is in some sense arbitrary and thus, we alternatively add $€ 5$ to the amount of donations, which leads to slightly lower absolute coefficient estimates due to the shift towards a less steep part of a logarithmic curve. These results are available upon request. We additionally estimate Poisson models in 5.3 , to avoid arbitrary adding of numbers.
} 
giving and the elasticities derived can be interpreted as "first-euro" price and income elasticities.

$X_{i t}$ summarizes the further control variables: Age, age squared, a dummy for living in East Germany, a dummy for being Christian, a dummy for applying spouse income splitting, and a dummy for having children. Additionally, the regional GDP and the regional unemployment rate in the respective federal state are included in X. The summary statistics of all control variables can be found in table 2 in the appendix.

The final step is to analyze the treatment effect of the introduction of the euro. The currency changeover from DM to euro was a one-time event happening on 1st January, 2002 and hence, the potential change on outcome is covered by the dummy for the year 2002.

Fehr and Tyran (2004) argue that money illusion may give rise to substantial but transitory nominal inertia in the aftermath of a change in monetary policy. Thus, it might be the case that the effect on donations is still visible in the year 2003. Since the year dummies are the most important explanatory variables of interest, the time fixed effect will be decomposed into the different years leading to the regression equation:

$$
\ln D O N_{i t}=\mu+\sigma_{1} D y 02_{t}+\sigma_{2} D y 03_{t}+\beta \ln I_{i t}^{H}+\delta \ln \left(1-\tau_{i t}^{H}\right)+X_{i t} \gamma+\alpha_{i}+\epsilon_{i t}
$$

The year dummy for 2001 serves as reference year. To study the effect of the euro introduction on donations, we in particular focus on the coefficient $\sigma_{1}$.

Table 1 demonstrates that the coefficients on the dummy for the year 2002 are positive and highly significant in the nominal benchmark model. Column 1 suggests that claimed donations in 2002 are $14.2 \%$ higher than in 2001 . The inclusion of further control variables leads to a smaller, but still substantial effect of $11.2 \%$. With the exception of the unemployment rate and the year dummy for 2003 all variables are highly significant in the full model. Concerning the persistence of money illusion, operationalized via the 2003 year dummy, it turns out that adding further control variables reduces its explanatory 
power.

The influence of the other control variables is as expected: The tax price of giving negatively impacts donations, as higher marginal tax rates lower the price of giving. Moreover, age has a positive influence on charitable giving, though, its effect is nonlinear with a negative squared coefficient. Being married and applying the spouse income splitting as well as having children are positively related to donations. The effect of regional GDP is positive, but close to zero. Unexpectedly and in contrast to most previous research the coefficient on income implies a negative relationship with claimed donations.

To derive results in real terms we deflate all monetary variables, i.e. donations, income and regional GDP. Here, it is important to note that inflation rates from 2001 to 2003 were rather low (2001: 2\%, 2002: 1.4\%, 2003: 1.1\%). Columns III and IV of table 1 show the inflation-adjusted benchmark results. The coefficient on the year dummy 2002 is still positive and highly significant in both specifications and as expected compared to the nominal benchmark model, the coefficients are slightly smaller. Column IV demonstrates that in 2002 inflation-adjusted or real donations were $10.8 \%$ higher than before the euro introduction. The benchmark model indicates that the year of the currency changeover was indeed accompanied by an unusual real increase in donations. This effect remains even after controlling for various individual and macroeconomic influence factors.

However, the benchmark model provides an upper bound of the causal euro introduction effect on giving behavior, as the coefficient on the year dummy may still contain the effects caused by other events happening in 2002. In the following, we thus decompose the 2002 year dummy further to identify more precisely the money illusion effect in course of the introduction of the euro. The first approach is based on reducing the plausibility of alternative explanations for the treatment effect and the second approach exploits variation across different donations categories. 


\subsection{Disaster-Adjusted Donation Index}

A major event that influenced donations and coincided with the timing of the currency changeover is a catastrophic river flooding along Elbe and Danube in August 2002. In the aftermath of the floods, damages were estimated to amount to approximately $€ 11$ billion. 370,000 people in the federal states of Saxonia, Saxony-Anhalt, Bavaria, Lower Saxony and Brandenburg were immediately affected and 21 people died. The floods caused a significant rise in donations with $€ 350$ million of private donations registered in Germany (Dehmer and Neuhaus 2012). To identify the effect on donations caused by the introduction of the euro is challenging in the light of this extreme event. Hence, controlling for donations caused by the flood is essential to establish a money illusion effect in the course of the introduction of the euro.

To control for a general-flood-effect, an improved identification approach uses disasteradjusted data on donations. To do so we use external information provided by the DZI (Deutsches Zentralinstitut für Sozial Fragen, German Central Institute for Social Issues). The mission of the DZI is to collect and document information on charities soliciting donations and to provide independent evaluations to donors. The charities that are part of the annual index are regularly interviewed on the amount of donations received in relation to a natural disaster of a certain year. Based on this information, the DZI calculates an annual disaster-adjusted donation index for Germany.

For 2002, the DZI reports a 3.9\% reduction in disaster-adjusted donations compared to the year 2001 and a $1.8 \%$ increase in 2003 compared to 2002 . We use this information in order to adjust claimed donations for disaster fluctuations in the same way we adjusted for inflation. The dependent variable, claimed donations, is now inflation and disasteradjusted and consequently the coefficients on the year dummies are expected to become smaller. The results are presented in column $\mathrm{V}$ of table 1 . The coefficient on the year dummy in 2002 is still positive and highly significant at the 1\%-level, however it decreased from 10.8 percent in column IV, to $7.6 \%$. The 2003 year dummy is slightly negative and remains insignificant. 
Aside from the introduction of the euro, inflation and the river floods are most likely the two main factors that determined an increase of donations in 2002 compared to 2001. Controlling for both we still find a significant increase in donations, which supports the evidence for a change in donation behavior due to the currency changeover.

\subsection{Incorporating data non-linearity}

A further critique that could apply to our estimations is the negligence of the nonlinear data structure of our donations variable. Figure $1 \mathrm{~b}$ demonstrates that charitable giving is highly nonlinear with roughly $50 \%$ of taxpayers that do not donate at all. Such high levels of non-donors lead often to the estimation of Tobit models. However, a consistent Tobit estimation relies on strong assumptions: The error term has to be normally distributed and homoskedastic and, the explanatory variables have to affect the donation decision equally along the extensive and the intensive margin. Furthermore, due to the incidental parameters problem, a fixed effects estimation of the Tobit model and thus, controlling for unobserved heterogeneity is not feasible.

In view of these econometric difficulties we rely on another nonlinear model, the fixed effects Poisson model (FEPM). The FEPM takes the non-linearity of donations data into account and controls for unobserved heterogeneity. Moreover, the FEPM has many desirable robustness properties for estimating the parameters in the conditional mean. In our case, except for the conditional mean, the distribution of $G$ given the control variables and the fixed effects is completely unrestricted and neither overdispersion nor underdispersion pose a problem for the estimation. Moreover, the model does not require a Poisson distribution. The parameter estimates can be directly interpreted as elasticities without the need for arbitrary adjustments to zero donations. Due to these favorable properties the FEPM is widely used in the estimation of gravity equations in international trade that possess a data structure similar to our donations data and which are also estimated as an alternative to linear constant elasticity models (see Santos Silva and Tenreyro, 2006). 
Column VI of table 1 depicts the results of the FEPM. Taking inflation, disaster adjustment and the non linear data structure into account reduces the euro introduction effect further to 2.4\%. Again, we cannot find that the effect persists in 2003, as the 2003 year dummy is neither economically nor statistically significant. With the exception of the significantly lower tax price of giving the coefficients for the remaining variables are comparable to the linear models.

Insert table 1 here

\section{Discussion and Conclusion}

In this paper we used the introduction of the euro in Germany as a natural experiment to empirically test whether people were prone to money illusion due to the currency changeover. Money illusion means that individuals are subject to a psychological bias caused by failing to distinguish between transactions in nominal and real terms. This work makes a contribution to current research by using administrative tax data and therefore provides evidence from an extensive sample of the German population. In doing so, the empirical strategy is to test whether the introduction of the euro led to an unusual real change in donations in the aftermath of the currency changeover. In line with a large body of literature, donations are modeled as a demand function dependent on the firsteuro income and the first-euro tax price of giving. Further control variables comprise regional GDP and, unemployment rate and various socio-demographic variables such as age and religion. Panel data estimation allows measuring variation within a tax unit while accounting for individual heterogeneity by adding tax unit specific fixed effects.

Since the currency changeover was an event occurring in a certain year, the money illusion effect is essentially measured by the year dummy for 2002. The positive and highly significant coefficient demonstrates that there was an unusual real increase in donations in this year. In contrast the coefficient in the year 2003 is almost zero and mostly insignificant which indicates that the money illusion effect disappears over time. With 
the intention to decompose the year dummy effect and to identify an effect which can solely be attributed to money illusion, we apply a disaster adjustment to our donations variable. The money illusion effect is estimated to be between $2.4 \%$ and $7.6 \%$. In 2001 , German taxpayers declared a total of $€ 3.7$ billion donations (Buschle 2006), hence, the effect has a magnitude of $€ 89$ to $€ 281$ million in absolute terms.

Compared to other studies our results are considerably lower than the $11 \%$ increase in charitable donations found by Kooreman et al. (2004) for the Netherlands and the 11\% for Italy and 13\% increase in donations for Ireland found by Cannon and Cipriani (2006). The settings of both Kooreman et al. as well as of Cannon and Cipriani involve doorto-door respectively face-to-face collections of charities. These situations give economic agents less time to make decisions so that cognitive difficulties in real price conversions become more manifest. Furthermore, face-to-face and door-to-door collections involve the well known "power of the ask" effect (see for instance Andreoni and Rao, 2011) as well as social pressure as an important determinant of the decision to donate (DellaVigna et al. 2012). Both effects might additionally bedevil decision-making and thus further enhance the money illusion effect. In contrast, our data source contains many donations made via bank transfers or even automatically converted standing orders, which would reduce the effect of money illusion considerably. This is in line with recent laboratory results (Petersen and Winn 2014). Changing the experimental framework of Fehr and Tyran (2001), for instance by providing a computerized income converter, they find money illusion to be less prevalent than in the initial design of Fehr and Tyran. Yet, to judge the effect of money illusion for charitable donations relative to the price of other goods it is important to include more ways of making donations than personal collections. We are thus confident that our measures provide a meaningful complement on the phenomenon of money illusion to previous research using the Euro introduction as a natural experiment. While a considerable "illusion component" remains, the consideration of all kinds of charitable donations leads to a convergence towards neutral money.

Despite its novelty of using administrative tax data to determine the scale of money 
illusion on an aggregate level for the whole economy, our study leaves room for future research. First, our research design could have been improved by adding more pretreatment observations. Including more years before the currency changeover would allow calculating a trend in the data. Unfortunately, in Germany no administrative income tax data is available in a panel dimension before 2001. Another constraint is the low frequency of data which is caused by the fact that tax files are handed in only once per year. Monthly data would allow a more accurate account for charity fluctuations such as the flood component in the donation behavior and could give a better picture of the adaption process to adjust for money illusion.

\section{$7 \quad$ References}

Akerlof, George A., and Janet L. Yellen. (1985). "Can small deviations from rationality make significant differences to economic equilibria?" American Economic Review 75, 708-720, September 1985.

Andreoni, James. (1990). "Impure altruism and donations to public goods: a theory of warm-glow giving." The Economic Journal 401, 464-477.

Andreoni, James. (2006). "Philanthropy." In Handbook of the Economics of Giving, Altruism and Reciprocity Applications, edited by Serge-Christophe Kolm and Jean Mercier Ythier, pp. 1201-1269, Amsterdam, NL: Elsevier.

Andreoni, James, and Justin Rao. (2011). "The power of asking: How communication affects selfishness, empathy, and altruism." Journal of Public Economics 95, 513-520.

Becker, Gary S. (1974). "A Theory of Social Interactions." The Journal of Political Economy 82, 1063-1093.

Buschle, Nicole. (2006). "Spenden in Deutschland, Ergebnisse der Einkommensteuerstatistik 2001." Wirtschaft und Statistik 2, 151-159. 
Cannon, Edmund S., and Giam P. Cipriani. (2006). "Euro-illusion: A natural experiment." Journal of Money, Credit, and Banking 38, 1391-1403.

Clotfelter, Charles T. (1985). Federal Tax Policy and Charitable Giving. Chicago, IL: The University of Chicago Press.

Clotfelter, Charles T. (2002). "The economics of giving." Giving better, giving smarter: Working papers of the national commission on philanthropy and civic renewal, 33-35.

Dehmer, Dagmar, and Carla Neuhaus. (2012). Zehn Jahre nach dem Elbe-Hochwasser. Aus der Flut gelernt?, http://www.tagesspiegel.de/politik/zehn-jahre-nach-dem-elbe-hochwasseraus-der-flut-gelernt/6990090.html (12.08.2012), Der Tagesspiegel Online

DellaVigna, Stefano, John A. List, and Ulrike Malmendier. (2012). "Testing for Altruism and Social Pressure in Charitable Giving." Quarterly Journal of Economics 127, 1-56.

Dunn, Elizabeth W., Lara B. Aknin, and Michael I. Norton. (2008). "Spending money on others promotes happiness." Science 319, 1687-1688.

Fehr, Ernst, and Jean-Robert Tyran. (2001). "Does Money Illusion Matter?" American Economic Review 91, 1239-1262.

Fehr, Ernst, and Jean-Robert Tyran. (2004). "Expectations and the Effects of Money Illusion." Techreport, Netherlands Central Bank.

Fisher, Irving. (1928). The money illusion. New York, NY: Adelphi Company.

Gerber, Ulrike, and Sebastian Hammer. (2013). "Das Taxpayer-Panel 2001 bis 2008." Statistisches Bundesamt, Wirtschaft und Statistik.

Glazer, Amihai, and Kai A. Konrad. (1996). "A signaling explanation for charity." American Economic Review 86, 1019-1028.

Grandmont, Jean-Michel. (1983). Money and Value. Cambridge, UK: Cambridge university press. 
Kooreman, Peter, Riemer P. Faber, and Heleen M.J. Hofmans. (2004). "Charity donations and the euro introduction: Some quasi-experimental evidence on money illusion." Journal of Money, Credit, and Banking 36, 1121-1124.

Leontief, Wassily W. (1936). "The Fundamental Assumption of Mr. Keynes' Monetary Theory of Unemployment." The Quarterly Journal of Economics 51, 192-197.

Lucas Jr, Robert E. (1972). "Expectations and the Neutrality of Money." Journal of Economic Theory 4, 103-124.

Petersen, Luba, and Abel Winn. (2014). "Does Money Illusion Matter? Comment." American Economic Review 104, 1047-1062.

Raghubir, Priya, and Joydeep Srivastava. (2002). "Effect of face value on product valuation in foreign currencies." Journal of Consumer Research 29, 335-347.

Shafir, Eldar, Peter Diamond, and Amos Tversky. (1997). "Money illusion." The Quarterly Journal of Economics 112, 341-374

Silva, J.M.C. Santos, and Silvana Tenreyro. (2006). "The log of gravity." The Review of Economics and Statistics 88, 641-658.

Soman, Dilip, Klaus Wertenbroch, and Amitava Chattopadhyay. (2002). "Currency Numerosity Effects on the Perceived Value of Transaction." INSEAD Working Paper Series No. 124/MKT.

Tversky, Amos, and Daniel Kahneman. (1974). "Judgment under uncertainty: Heuristics and biases." Science 185, 1124-1131. 


\section{Appendix}

Figure 2: Number of tax units

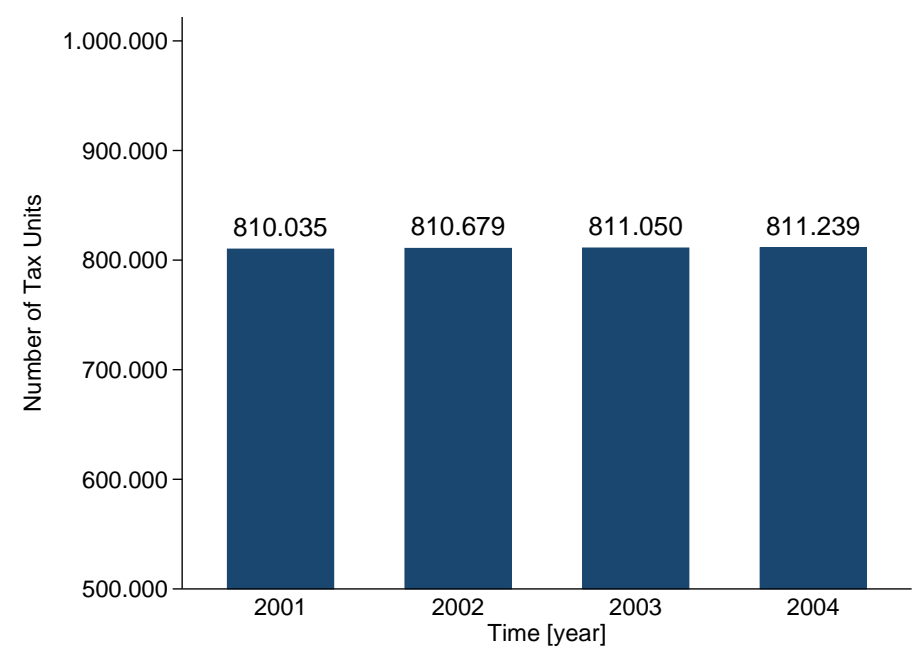




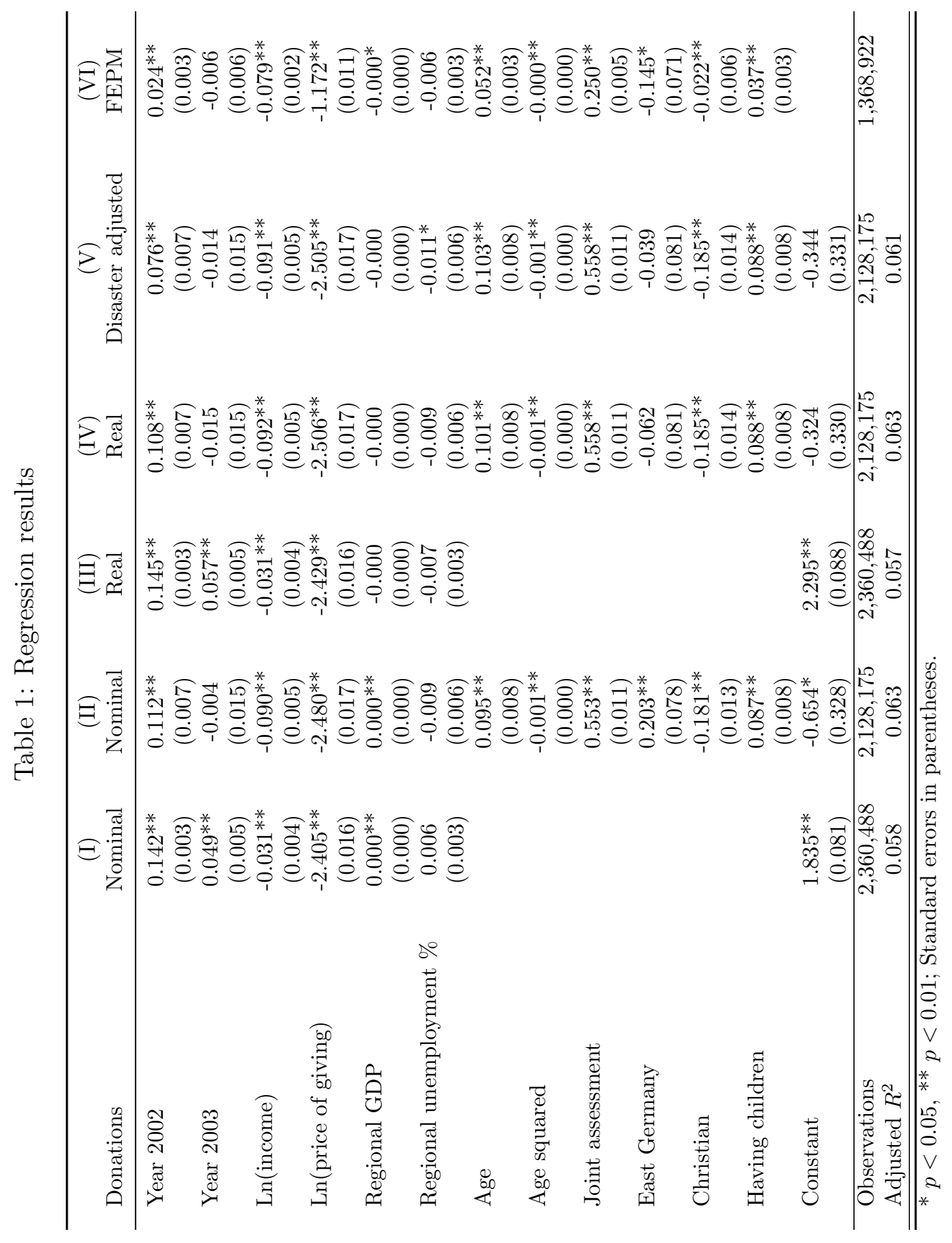


Table 2: Descriptive Statistics for all Control Variables

\begin{tabular}{lcccc}
\hline Year & 2001 & 2002 & 2003 & 2004 \\
\hline Income [€] & $82,384.29$ & $80,961.12$ & $82,315.14$ & $90,968.39$ \\
& $(784.03)$ & $(591.62)$ & $(628.548)$ & $(722.20)$ \\
Tax price of giving & 0.71 & 0.70 & 0.70 & 0.72 \\
& $(0.000)$ & $(0.000)$ & $(0.000)$ & $(0.000)$ \\
BIP [1M] & 681,122 & 691,279 & 696,357 & 714,708 \\
& $(785.83)$ & $(796.45)$ & $(802.407)$ & $(824.77)$ \\
Unemployment Rate [\%] & 8.87 & 9.29 & 10.08 & 10.13 \\
& $(0.0045)$ & $(0.004)$ & $(0.004)$ & $(0.0044)$ \\
Age [year] & 45.61 & 46.61 & 47.6 & 48.59 \\
& $(0.013)$ & $(0.0134)$ & $(0.0134)$ & $(0.0134)$ \\
Splitting share [\%] & 68.33 & 69.00 & 69.49 & 69.80 \\
& $(0.05)$ & $(0.05)$ & $(0.05)$ & $(0.05)$ \\
East share [\%] & 17.03 & 17.02 & 17.01 & 17.06 \\
Christian share [\%] & $(0.04)$ & $(0.042)$ & $(0.042)$ & $(0.042)$ \\
Having children & 58.68 & 58.36 & 57.67 & 56.84 \\
& $(0.058)$ & $(0.058)$ & $(0.058)$ & $(0.058)$ \\
& 53.51 & 53.16 & 52.90 & 52.37 \\
& $(0.055)$ & $(0.055)$ & $(0.055)$ & $(0.055)$ \\
\hline
\end{tabular}

Note: Standard errors of the mean in parentheses

Means of GDP and unemployment rate are averaged over tax units. 
Table 3: Regional GDP [€1M] for all German Federal States at Current Prices

\begin{tabular}{lllllllll}
\hline & BW & BY & BE & BB & HB & HH & HE & MV \\
2001 & 309,209 & 352,466 & 82,117 & 44,792 & 22,885 & 80,677 & 195,057 & 29,651 \\
2002 & 311,982 & 362,544 & 82,095 & 45,136 & 23,497 & 82,092 & 196,502 & 29,710 \\
2003 & 314,649 & 363,997 & 81,195 & 45,285 & 23,977 & 82,020 & 200,689 & 29,772 \\
2004 & 319,205 & 373,973 & 80,999 & 46,660 & 24,124 & 84,007 & 203,599 & 30,452 \\
\hline & NI & NW & RP & SL & SN & ST & SH & TH \\
2001 & 179,542 & 464,865 & 91,730 & 25,371 & 76,467 & 42,665 & 64,830 & 39,577 \\
2002 & 178,754 & 473,363 & 93,880 & 25,423 & 79,021 & 44,060 & 64,151 & 39,990 \\
2003 & 180,518 & 475,132 & 94,505 & 25,652 & 80,337 & 44,173 & 64,972 & 40,627 \\
2004 & 184,627 & 487,566 & 97,421 & 26,872 & 82,851 & 45,265 & 66,291 & 41,787 \\
\hline
\end{tabular}

Source: Working Group 'Volkswirtschaftliche Gesamtrechnungen der Länder'

https://www.genesis.destatis.de or http://www.vgrdl.de

BW: Baden-Württemberg, BY: Bavaria, BE: Berlin, BB: Brandenburg,

HB: Bremen, HH: Hamburg, HE: Hessen, MV: Mecklenburg-Vorpommern NI: Niedersachsen, NW: Nordrhein-Westfalen, RP: Rheinland-Pfalz, SL: Saarland, SN: Sachsen, ST: Sachsen-Anhalt, SH: Schleswig-Holstein ,TH: Thüringen

Table 4: Regional Unemployment Rate in \% for all Federal States

\begin{tabular}{lllllllll}
\hline & BW & BY & BE & BB & HB & HH & HE & MV \\
2001 & 4.9 & 5.3 & 16.1 & 17.4 & 12.4 & 8.3 & 6.6 & 18.3 \\
2002 & 5.4 & 6.0 & 16.9 & 17.5 & 12.5 & 9.0 & 7.0 & 18.6 \\
2003 & 6.2 & 6.9 & 18.1 & 18.8 & 13.2 & 9.9 & 7.9 & 20.1 \\
2004 & 6.2 & 6.9 & 17.7 & 18.7 & 13.2 & 9.7 & 8.2 & 20.4 \\
\hline & NI & NW & RP & SL & SN & ST & SH & TH \\
2001 & 9.1 & 8.8 & 6.8 & 9.0 & 17.5 & 19.7 & 8.4 & 15.3 \\
2002 & 9.2 & 9.2 & 7.2 & 9.1 & 17.8 & 19.6 & 8.7 & 15.9 \\
2003 & 9.6 & 10.0 & 7.7 & 9.5 & 17.9 & 20.5 & 9.7 & 16.7 \\
2004 & 9.6 & 10.2 & 7.7 & 9.2 & 17.8 & 20.3 & 9.8 & 16.7 \\
\hline
\end{tabular}

Source: Working Group 'Volkswirtschaftliche Gesamtrechnungen der Länder'

https://www.genesis.destatis.de or http://www.vgrdl.de

BW: Baden-Württemberg, BY: Bavaria, BE: Berlin, BB: Brandenburg,

HB: Bremen, HH: Hamburg, HE: Hessen, MV: Mecklenburg-Vorpommern NI: Niedersachsen, NW: Nordrhein-Westfalen,

RP: Rheinland-Pfalz, SL: Saarland, SN: Sachsen, ST: Sachsen-Anhalt, SH: Schleswig-Holstein ,TH: Thüringen 